
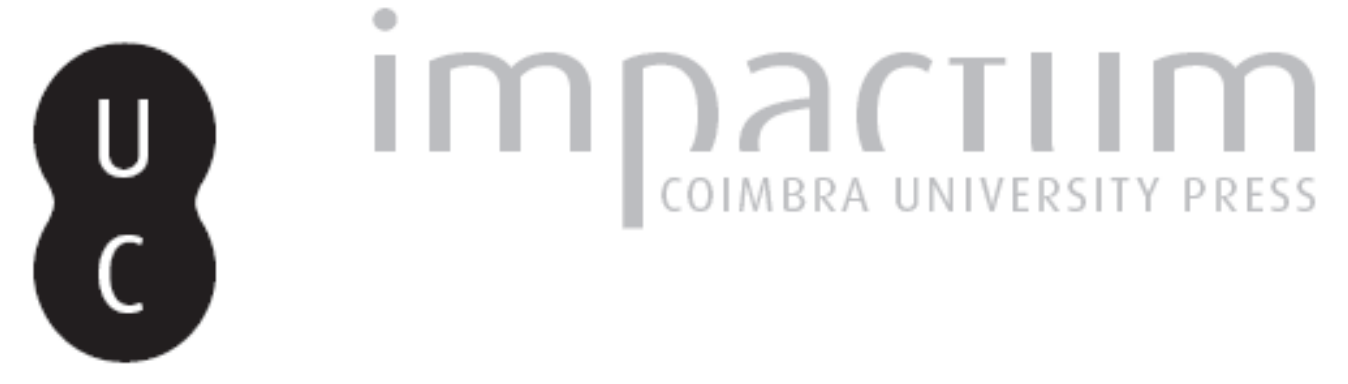

\title{
"Minha vida sem ti é como uma enxada sem cabo!": um olhar etnográfico sobre a educação numa escola de Moçambique
}

Autor(es): $\quad$ Portela, Joana Abranches

Publicado por: CIAS - Centro de Investigação em Antropologia e Saúde

URL persistente:

URI:http://hdl.handle.net/10316.2/28574

DOI:

DOI:http://dx.doi.org/10.14195/2182-7982_28_3

Accessed : $\quad$ 26-Apr-2023 16:19:29

A navegação consulta e descarregamento dos títulos inseridos nas Bibliotecas Digitais UC Digitalis, UC Pombalina e UC Impactum, pressupõem a aceitação plena e sem reservas dos Termos e Condições de Uso destas Bibliotecas Digitais, disponíveis em https://digitalis.uc.pt/pt-pt/termos.

Conforme exposto nos referidos Termos e Condições de Uso, o descarregamento de títulos de acesso restrito requer uma licença válida de autorização devendo o utilizador aceder ao(s) documento(s) a partir de um endereço de IP da instituição detentora da supramencionada licença.

Ao utilizador é apenas permitido o descarregamento para uso pessoal, pelo que o emprego do(s) título(s) descarregado(s) para outro fim, designadamente comercial, carece de autorização do respetivo autor ou editor da obra.

Na medida em que todas as obras da UC Digitalis se encontram protegidas pelo Código do Direito de Autor e Direitos Conexos e demais legislação aplicável, toda a cópia, parcial ou total, deste documento, nos casos em que é legalmente admitida, deverá conter ou fazer-se acompanhar por este aviso.

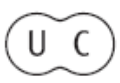




\section{Antropologia Portuguesa}

Departamento de Antropologia | Universidade de Coimbra

Volume $28 \cdot 2011$ 


\section{"Minha vida sem ti é como uma enxada sem cabo!" Um olhar etnográfico sobre a educação numa escola de Moçambique}

\section{Joana Abranches Portela}

Av. Nossa Senhora da Alegria, 35-5. D Dto - 3800-407 Aveiro, Portugal

joana.portela75@gmail.com

Resumo Neste artigo faz-se uma reflexão sobre alguns aspectos relativos à educação em Moçambique, com base na análise da nossa experiência pedagógica numa escola secundária na região da Angónia. Numa primeira parte, são abordadas questões de índole metodológica relacionadas com a nossa inserção no terreno e as suas diferentes fases: chegada, identificação, adaptação. Numa segunda parte damos especial atenção aos problemas que se colocam no ensino e aprendizagem da língua portuguesa; à importância da educação informal num sistema de ensino centralizado nos currículos formais; ao desfasamento entre o discurso político de incentivo à educação das raparigas e as práticas quotidianas. Por fim, dá-se conta de uma mudança de perspectiva pessoal no modo como encarámos o nosso papel educativo no confronto com o Outro e procuramos compreender como a diversidade e criatividade linguística dos estudantes de uma zona de fronteira reflectem múltiplas identidades.

Palavras-chave Educação; língua; identidade; Outro; fronteira.

Abstract This article discusses some aspects concerning education in Mozambique, based in the analysis of our teaching experience at a high school in the region of Angónia. Firstly we consider some questions of methodology related to our fieldwork and its different phases: arriving, identification, adaptation. Secondly, we focus on the problems aroused in the process of teaching and learning the Portuguese language; on the importance of informal education within a system centralized on formal curricula; on the discordance between the political discourse promoting girls' education and the ordinary practices. Finally, we acknowledge a personal perspective change on the way we regarded our educational role in the interaction with the Other and we intent at understanding how the linguistic diversity and creativity of students who live in a border region reflect their multiple identities.

Key words Education; language; identity; Other; frontier. 


\section{Texto e contexto}

O presente artigo resulta de uma reflexão, realizada a posteriori, sobre a minha experiência como professora de Português numa escola secundária moçambicana, durante os dois anos em que vivi, ensinei (e aprendi) na Missão de Fonte Boa, em Moçambique. A presença no terreno decorreu entre Dezembro de 2002 e Dezembro de 2004, como voluntária da ONGD Leigos para o Desenvolvimento, no âmbito de um projecto na área da educação.

A Missão de Fonte Boa fica situada no planalto da Angónia, no extremo nordeste da província de Tete, perto da fronteira com o Malawi e a $240 \mathrm{~km}$ da cidade moçambicana mais próxima (Tete). A Angónia é uma região marcadamente rural, com uma população pobre e maioritariamente analfabeta, que vive da agricultura de subsistência. As vilas mais próximas de Fonte Boa são, em Moçambique, a Vila Ulongué, a cerca de $15 \mathrm{~km}$, e Ntcheu (no Malawi), a $30 \mathrm{~km}$. Entre estas duas vilas e a Missão, ao longo da estrada de terra batida, sucedem-se os terrenos agrícolas e várias aldeias de palhotas. O território da Missão de Fonte Boa, graças à presença de congregações religiosas e, sobretudo, de infra-estruturas ao nível da educação e saúde, constitui um pólo de afluência e de dinamismo numa região densamente povoada, mas com escassos equipamentos sociais. $\mathrm{Na}$ Missão funcionam o único centro de saúde com maternidade e a única escola secundária $\left(8^{\circ}\right.$ a $10^{\circ}$ ano), com internato feminino e masculino, que servem a população das comunidades circundantes, num raio de muitos quilómetros.

A presença continuada dos Leigos para o Desenvolvimento em Fonte Boa verificava-se desde 1995, com a colaboração regular dos voluntários, a pedido das autoridades educativas, na escola da Missão (nacionalizada depois da independência), sobretudo ao nível do ensino de Português e Matemática, disciplinas onde a escassez de professores tem sido mais dramática. Assim, as comunidades locais estavam já habituadas à presença de leigos portugueses, quer em projectos educativos e sociais na Missão, quer como professores na escola de Fonte Boa.

$\mathrm{O}$ projecto de desenvolvimento que fui integrar - juntamente com o Carlos, meu marido - incluía, além da colaboração na escola como professores, a responsabilidade pela biblioteca e ludoteca da Missão, por um centro de formação em informática e a coordenação de um projecto de bolsas de estudo para alunas e alunos mais carenciados. É neste contexto e nestes espaços educativos que, ao longo de dois anos lectivos, pude acompanhar de perto o dia-a-dia dos cerca de 600 estudantes que, na altura, frequentavam a Escola Secundária de Fonte Boa. 


\section{Metodologia de investigação}

A metodologia de investigação adoptada neste estudo é a etnografia, entendida como um processo que "supõe um período prolongado de permanência no terreno, cuja vivência é materializada no diário de campo, e em que o instrumento principal de recolha de dados é a própria pessoa do investigador, através de um procedimento geralmente designado por observação participante" (Caria, 2002: 12). A pesquisa etnográfica permite o envolvimento do investigador no contexto de estudo e a observação participante possibilita a recolha de dados pormenorizados e de relatos na própria linguagem dos participantes (Burgess, 1997: 86).

Embora o meu papel social no terreno não tenha sido o de investigadora, nem a pesquisa etnográfica o objectivo deliberado desta experiência de campo, a estratégia que me permitiu recolher elementos informativos para apreender o contexto e a cultura envolvente foi a observação participante. Como professora e como voluntária da ONG, partilhei das rotinas sociais e culturais da escola e da Missão, vivendo-as "por dentro" e participando como actora na realidade social que viria a adoptar como objecto de análise. Talvez seja até mais exacto redefinir aqui como "participação observante" a metodologia subjacente a este estudo, na medida em que a observação, como técnica de recolha de dados, não foi predeterminada por um intuito de investigação, antes decorreu, naturalmente, da minha condição como professora a participar num contexto educativo e cultural que me era estranho e suscitava perplexidades. Ou seja, não participei na realidade para a poder observar; antes observei porque dela participava, estando simultaneamente dentro do contexto, mas com um olhar que não deixa de ser "de fora".

Durante os dois anos em que vivi em Fonte Boa, fui registando numa espécie de diário de campo as minhas observações e reflexões sobre as pessoas, a cultura e os acontecimentos que me rodeavam. As notas de terreno não eram redigidas in situ, mas posteriormente, com uma regularidade semanal. Fazia-o na calma dos domingos de manhã, recorrendo à memória. Por isso, esta transposição dos dados à escrita era já um processo de construção de sentido ${ }^{1}$.

${ }^{1}$ Cf. Fernandes (2002: 24): “O texto é um ponto de fixação das realidades que os órgãos do sentido captaram - mas é também o lugar da construção do seu significado sócio-cultural e o lugar donde emanará a grounded theory que os dados autorizam." 
Hoje, passados mais de três anos sobre o regresso de Moçambique, e agora já distanciada do contexto em análise, retomo as notas de campo então registadas para racionalizar essa experiência à luz de um enquadramento teórico. Assim, neste artigo, pretendo "conjugar e fazer coexistir a linguagem da experiência, de estar e pensar no trabalho de campo, com a linguagem da teoria, que permite objectivar e racionalizar o que ocorreu" (Caria, 2002: 10).

\section{“Estou só a ficar..." - a entrada no terreno}

Cheguei a Fonte Boa, com o meu marido, em meados de Dezembro de 2002, numa altura em que decorriam as férias escolares. $\mathrm{O}$ ano lectivo começaria daí a um mês. Da comunidade de leigos que íamos substituir, já só uma voluntária permanecia ainda no terreno. Ficara à nossa espera para fazer a transição, a "passagem de testemunho" dos projectos, e para nos apresentar ao contexto local. Assim, durante o primeiro mês, a nossa entrada no terreno foi facilitada pela presença da Ana, que estivera em Fonte Boa durante os três anos anteriores. Foi através dela que fomos apresentados às comunidades religiosas de jesuítas e irmãs responsáveis pela Missão, e à direcção da Escola Secundária de Fonte Boa, onde seríamos integrados como professores. Assim, grande parte dos nossos contactos iniciais foram muito facilitados pelo facto de termos sido acompanhados por alguém que gozava da confiança da comunidade e tinha já um sólido conhecimento da realidade local2.

A nossa chegada ao terreno era já há muito aguardada, quer pelos responsáveis religiosos da Missão, quer pelos professores e direcção da escola, quer pela própria comunidade local envolvente, habituada desde 1995 à presença contínua (renovada de dois em dois anos) de voluntários da referida ONG. Por isso, nos dias que se seguiram à nossa chegada a Fonte Boa, recebemos a visita de algumas pessoas da comunidade, que vinham à casa dos leigos para nos conhecer e, sobretudo, para se despedirem da voluntária que regressava definitivamente a Portugal. A maior parte das visitas que tivemos durante esse primeiro mês no terreno foi de alunos (ainda em férias) e de ex-alunos da escola da Missão, que tinham mantido uma

${ }^{2}$ Cf. Portela (1985: 172): "Na fase inicial, é necessário identificar e obter a cooperação dos indivíduos que assegurarão os primeiros contactos entre o investigador e o grupo ou comunidade a estudar, o que exige naturalmente um certo tempo. A confiança que a sociedade local deposita naqueles indivíduos é, em certa medida, "transferida" para o investigador." 
relação próxima com os leigos que nos antecederam. Vinham não só para se despedirem da Ana, mas também para encetar connosco uma relação de proximidade, como se transferissem agora para nós o capital afectivo que tinham acumulado junto dos voluntários anteriores.

Numa dessas visitas aprendi aquela que haveria de ser a minha atitude ao longo do primeiro mês no terreno. Recordo aqui o episódio: ainda em tempo de férias escolares, recebemos a visita de um ex-aluno da Ana. Depois de longo tempo passado no alpendre de nossa casa, numa conversa entremeada de muitos e longos silêncios, despedimo-nos dele e reentrámos em casa. Mais de meia hora passada, saio de novo para o alpendre e espanto-me ao ver o rapaz ainda lá, sentado, sem fazer nada e como se estivesse à espera de alguma coisa - pensava eu. Surpreendida, perguntei-lhe por que razão ainda estava ali. Respondeu-me: "Estou só a ficar..."

Ainda desconhecedora dos hábitos sociais daquele povo, primeiro fiquei completamente desconcertada com a resposta, que batia de frente com o meu preconceito ocidental de gestão eficiente do tempo. Mais tarde percebi que estava ali a chave que eu própria deveria adoptar e que me permitiria apreender o contexto cultural em que agora me movia. Hoje, à distância, compreendo como esta atitude de "estar só a ficar" é determinante para conseguirmos chegar às pessoas, seja numa experiência etnográfica, seja num projecto de desenvolvimento ${ }^{3}$. Uns dias depois de ter aprendido o que era "estar só a ficar", escrevi estas notas:

12 de Janeiro de 2003

Chegámos a Fonte Boa há quase um mês. É bom sentir que aqui, felizmente, o tempo passa mais devagar. (...) Temos tido muito tempo para conhecer os lugares e as pessoas, para estar e ficar... Também é verdade que agora há mais tempo livre porque as aulas ainda não começaram. Temos estado a ambientar-nos a este novo mundo e a receber os diversos projectos das mãos da Ana, que agora está de partida. Não há dúvida de que os diversos Leigos para o Desenvolvimento que por aqui passam têm feito um trabalho notável, mas que só é verdadeiramente perceptível para quem está no terreno. (...) Também só no terreno é que é possível apercebermo-nos das enormes carências deste país. Chega a ser difícil de acreditar...

${ }^{3}$ Ao relembrar este episódio, vejo-o agora como um exemplo daquilo que escreve Caria (2002: 12): “O etnógrafo é objecto de processos de socialização local que o obrigam a evidenciar as suas inseguranças e perplexidades e a relativizar as suas origens culturais. (...) Tem que se pensar a si próprio na relação com o outro." 


\section{"Azungo, azungo" - a fase de identificação}

No decorrer do primeiro mês, procurei deixar-me ficar e observar a realidade, sem procurar ainda escrutiná-la. Mas, na mesma medida em que eu observava o contexto e as pessoas que me rodeavam, era eu própria um permanente alvo de observação e de interrogação. O aspecto dominante dos primeiros dias foi o da nossa identificação. Quem éramos, porque vínhamos? Porque não tínhamos filhos, sendo casados? Porque tínhamos deixado Portugal e a família para vir viver no mato? A nossa múltipla condição de brancos, portugueses, voluntários, leigos e professores recém-chegados significava, antes de mais, que éramos desconhecidos, estranhos (para alguns até mesmo intrusos), com um determinado status e a quem, de imediato, se atribui um certo número de características e comportamentos.

Durante esse tempo inicial, junto dos alunos (apenas rapazes) que nos visitaram - a maior parte dos quais terminara já o $10^{\circ}$ ano e passara a estudar na vila - senti que havia uma enorme gratidão para com os voluntários anteriores e uma vontade explícita de projectar em nós, recém-chegados, essa amizade e perpetuá-la. Mas senti igualmente que, junto da direcção da escola e dos professores locais, havia desde o primeiro momento uma certa hostilidade para connosco, como resultado de situações de tensão, e até de conflito, ocorridas durante o ano lectivo anterior entre os leigos que nos precederam e a comunidade docente local.

Como os voluntários da ONGD Leigos para o Desenvolvimento se vão revezando no terreno e pertencem a uma mesma organização, com princípios de actuação comuns, as populações locais vão construindo uma imagem, um estereótipo, do "leigo". Assim, quando um novo voluntário ou voluntária chega à Missão, essa imagem de alteridade é imediatamente projectada no recém-chegado e este acaba por herdar as expectativas e, em grande medida, o tipo de relacionamento que os locais mantiveram com os leigos anteriores.

Fora da comunidade escolar, a nossa presença no terreno era desejada e acarinhada pelas populações vizinhas. Não éramos vistos como intrusos, mas como "os amigos lá de Portugal que vêm para nos ajudar". Esta expectativa viria a ser muitas vezes motivo de mal-entendidos, na medida em que a nossa intervenção social passava por desenvolver projectos na área da educação, mas não por distribuir bens ou ajudas monetárias. Aliás, esta expectativa de ajuda material está também associada ao estereótipo local 
do azungo (branco, europeu), visto como o antigo colonizador que agora regressa com projectos assistencialistas.

Se, dentro do recinto da Missão e do contexto escolar, o nosso papel social foi sendo percebido como missionários (e) professores, fora daqueles limites, e durante os primeiros meses, éramos vistos essencialmente como azungo. Este papel do Outro, apesar das nossas tentativas de inculturação, estava-nos colado à pele. Isto, senti-o inúmeras vezes, a ponto de me ser desconfortável esta diferença. As notas de terreno que registei alguns meses depois apenas vêm confirmar que a identificação do observador é um processo que se vai estendendo ao longo do tempo e não algo adquirido de uma vez por todas.

26 de Maio de 2003

Apesar de já estarmos aqui na Missão há mais de cinco meses, é a curiosidade da população a tónica dominante das nossas visitas ao novo mercado da Fonte Boa. Há três semanas foi um acontecimento: começou a funcionar um mercado (eminentemente malawiano) na zona das bancas do Magumbo, a aldeia contígua à Missão. $\mathrm{O}$ dia de mercado é à segunda-feira e tem sido uma excitação, sobretudo para os alunos (já que o mercado mais próximo era o da Vila Ulongué, a $15 \mathrm{~km}$ e a três horas a pé!). Desde então, nas tardes de segunda-feira, a biblioteca fica bastante mais vazia, e o mesmo se passa com o recinto da escola. Os alunos invadem o mercado, cheios de curiosidade, e andam por lá a deambular e (infelizmente) a malbaratar o pouco dinheiro que têm. De repente, apareceram vários alunos com sapatos novos...

Mas é a curiosidade dos locais que marca as nossas breves idas ao mercado. Quando passamos, todos os olhares se voltam ostensivamente para nós, certamente por sermos brancos e, talvez, por passearmos de mão dada (um homem e uma mulher de mão dada aqui é impensável, pois o que é natural e muito comum é ver dois homens de mãos dadas; os alunos rapazes andam sempre de mão dada uns com os outros - nas raparigas já é muito raro - mas sem que isso represente uma orientação homossexual). E lá vamos ouvindo "azungo, azungo" ("branco, branco"), o que por cá é quase sinónimo de "dinheiro, dinheiro", apesar de nós sermos muito parcos nas nossas despesas e regatearmos o preço até nos cobrarem o mesmo que aos locais. Confesso que me sinto bastante desconfortável ao sentir que somos nós a principal atracção sempre que lá vamos. Há crianças pequenas que ainda choram ao ver um branco... Já me aconteceu várias vezes, até na própria Missão! 


\section{“Estou pedir conversa..." - a fase de adaptação}

Uma reflexão agora distanciada sobre esta experiência no terreno leva-me a concluir que, com o regresso da nossa acompanhante inicial a Portugal, seguiu-se um outro período que podemos designar por fase de adaptação, que se prolongou por vários meses. Esta etapa foi marcada, por um lado, pelas nossas iniciativas deliberadas de inculturação e, por outro, pelas grandes dificuldades ao nível da comunicação.

A necessidade de me aproximar dos alunos e alunas e da população local, de me tornar mais familiar, tentando minimizar o meu papel como estranha, levou a que, nos primeiros tempos, me fizesse presente em determinados contextos sociais, nomeadamente na eucaristia dominical da comunidade e nas missas dos estudantes; nas idas ao mercado da vila; nos passeios pelas redondezas e pela extensa área da própria Missão. Foi um período marcado pelo desejo de me tornar parte integrante do contexto e ganhar a confiança dos estudantes e da população. Satisfeita a curiosidade inicial, as pessoas foram-se habituando à nossa presença.

Mas fazer-me presente não era o mesmo que conseguir comunicar. E foi aqui que encontrei um dos primeiros grandes obstáculos, ao dar-me conta de que a maior parte das pessoas não falava português. Não eram apenas as diferenças culturais a cavar um fosso ao nível da comunicação, era acima de tudo a inexistência de uma língua comum. Muitas vezes, ao tentar conversar com a população local, tive essa experiência de sentir que há domínios em que a comunicação não é possível para além do sorriso. Nem sequer os gestos são universais.

Assim, um projecto que persegui nas primeiras semanas foi o de aprender o dialecto local - o cinyanja. Em casa havia manuais, gramáticas e dicionários, mas o problema foi encontrar quem me ensinasse... No início do ano lectivo, cheguei a ter aulas de conversação com dois alunos que tinham terminado o $10^{\circ}$ ano e me tinham sido recomendados, mas depressa concluí que com eles pouco mais poderia aprender de cinyanja do que algum vocabulário. As regularidades da língua, a sua lógica interna, as suas normas gramaticais, também eles as desconheciam. Tinham do cinyanja apenas o conhecimento intuitivo e pragmático de quem usa a língua sem nunca a ter pensado.

Depois de ter estudado as primeiras lições da gramática cinyanja e de me aperceber como a estrutura conceptual da língua era tão diferente 
do português, com categorias de pensamento tão alheias à forma de pensar nas línguas indo-europeias, não só desisti do projecto, que implicaria um extraordinário investimento de tempo, de estudo e uma mudança de paradigma mental, como antevi as grandes dificuldades que me esperavam como professora de Português junto de uma população cuja língua materna é de origem bantu ${ }^{4}$. Esta previsão consolidou-se quando constatei que os estudantes não adquiriam na escola primária, como seria de esperar, competências linguísticas ao nível da língua portuguesa.

12 de Janeiro de 2003

Aqui, o tempo demora-se, sem pressas, na soleira da porta, à volta de uma refeição, nos silêncios de uma criança que chega e diz "Estou pedir conversa", mas que não sabe de português mais do que cinco ou seis palavras. (...) A Missão está sempre cheia de crianças das aldeias aqui ao lado. Como não falam português, a comunicação torna-se muito difícil. Algumas já andam na escola, cujo ensino supostamente é em português, mas chegam à $4^{\mathrm{a}}$ classe sem saberem falar a língua oficial. (...) O Zacarias ( $2^{\mathrm{a}}$ classe) é o visitante habitual e o vocabulário português dele, que é reduzidíssimo, vai aumentando consoante os pedidos que vem fazer: "Estou pedir bola", "Estou pedir futebol", "Estou pedir sapatilha", "Estou pedir camisa", "Estou pedir sabão". O Zacarias já assimilou a atitude nacional dos Moçambicanos face aos estrangeiros: "Estou pedir..."

Quando as crianças invadiam o nosso alpendre com pedidos deste teor, eu passei a responder: "E eu estou a pedir conversa". Fazia-o com a dupla intenção de estimular neles a conversação em português e de transmitir a ideia de que não estávamos ali para distribuir bens materiais, mas para ajudá-los a aprender e para aprender com eles. Sendo muito difícil a comunicação com estas crianças, não era com palavras que conseguíamos desconstruir o seu preconceito do azungo como o Outro rico e paternalista que distribui dólares e canetas.

O meu primeiro contacto com o desconhecimento da língua portuguesa foi com estas crianças que apareciam na Missão e com as populações vizi-

\footnotetext{
${ }^{4}$ Segundo os dados do recenseamento geral de 1997, 74\% dos moçambicanos que vivem em meio rural têm uma língua bantu como língua materna e $89 \%$ da população do distrito da Angónia, com cinco anos ou mais de idade, não sabe português.
} 
nhas. Mas quando começaram as aulas, aumentou a minha perplexidade ante a falta de competências linguísticas dos estudantes do secundário na sua língua oficial.

16 de Fevereiro de 2003

A mundivisão destes alunos e os seus horizontes de conhecimentos são tão limitados que se torna muito difícil para eles e para nós falarmos a mesma linguagem. Na minha turma do $8^{\circ}$ ano, nenhum aluno sabia o que é "aventura" nem "fada". No $9^{\circ}$ ano, apenas um dos 130 alunos do Carlos já tinha utilizado um telefone.

Agora, ao reler as notas de terreno escritas um mês depois da chegada, o que me surpreende já não é que os meus alunos e alunas não soubessem o que significa "fada". Surpreende-me, sim, que isso me tivesse causado perplexidade, já que "fada" é claramente um conceito do quadro cultural de um europeu, não de um moçambicano! Surpreende-me que não tenha sido capaz de, então, lhes fazer um paralelismo entre as nossas fadas e os seus espíritos dos antepassados. Hoje já não me revejo nessas reflexões que então escrevi e preciso de as reformular: a minha mundivisão e os meus horizontes de conhecimentos são tão limitados que se torna muito difícil para eles e para nós falarmos a mesma linguagem ${ }^{5}$.

A fase de adaptação ao terreno foi tendo ritmos diversos consoante os diferentes contextos sociais em que nos movíamos. A busca do nosso lugar e do nosso papel no contexto educativo foi o maior desafio sentido ao longo do primeiro ano. As dificuldades de adaptação surgiram não tanto no que diz respeito à relação com os estudantes, mas sobretudo no que se refere ao nosso enquadramento no sistema de ensino oficial, nas suas políticas de ensino da língua, na relação com a direcção da escola e os professores locais.

Surpreendia-me com as práticas pedagógicas e incomodava-me a estratégia de ensino seguida pela própria direcção da escola. $\mathrm{O}$ formalismo do sistema em que tivemos de nos integrar foi um escolho durante todo o tempo de permanência no terreno e a adaptação nunca plenamente conse-

${ }^{5}$ Cf. Fernandes (2002: 24): "Levar a bom termo uma pesquisa etnográfica é uma actividade profundamente especializada, talhada numa longa aprendizagem que exige o confronto e a transformação pessoais. Se o trabalho respeitar todas as exigências que lhe são próprias, o etnógrafo não sairá incólume da experiência que viveu." 
guida. Durante esta fase, os registos do diário de campo deixam perceber como as resistências, os preconceitos e as perplexidades eram bidireccionais.

16 de Fevereiro de 2003

Estamos os dois a dar Português: eu a três turmas do $8^{\circ}$ ano e o Carlos a três turmas do $9^{\circ}$ ano. Parece um pouco estranha esta distribuição... ${ }^{6}$ Ainda por cima tendo em conta que a escola tem até ao $10^{\circ}$ ano e é um professor moçambicano (um escolástico), bacharel em Filosofia num país francófono, quem está a dar este nível de Português. Quando nos foi apresentada esta distribuição, eu ainda tentei negociar com ele para ser eu a dar o $10^{\circ}$ ano, já que tenho formação específica na área, mas ele recusou com o argumento de que tinha passado as férias a preparar as aulas do $10^{\mathrm{a}}$ ano... Na altura fiquei bastante frustrada com este desperdício de recursos por parte da escola, mas pode ser que Deus escreva direito por linhas tortas e o facto de ser eu a dar Português a um nível mais baixo seja uma forma de os alunos adquirirem melhores bases...

Apesar de cada um de nós só ter 15 tempos lectivos, a escola tomanos muito tempo, não só na preparação das aulas, mas também com outras formalidades. Como o nível pedagógico dos professores é bastante mau (a maior parte tem apenas o $10^{\circ}$ ano), há uma série de mecanismos para ir controlando o desempenho pedagógico. No início de cada período, todos somos obrigados a fazer uma planificação trimestral dos conteúdos a leccionar em cada semana. Depois, semanalmente, temos que apresentar a planificação das aulas da semana, isto é, os conteúdos que vamos dar em cada aula. E antes de cada aula, temos que apresentar o plano de aula, com objectivos, conteúdos e estratégias... Todas estas planificações - trimestral, semanal e diária - têm que receber a assinatura de supervisão e aval do director pedagógico (que nem licenciado é!...). No nosso caso, ele limita-se a assinar de cruz, não sei o que

${ }^{6}$ Importa aqui um esclarecimento relativo à nossa formação académica. Eu sou licenciada em Línguas e Literaturas Clássicas e Portuguesa, via ensino, com habilitação própria como professora de Português. O meu marido é licenciado em Engenharia Física, sem formação pedagógica. Antes de partimos para Moçambique, tinha sido acordado com a direcção da escola que o Carlos iria leccionar a disciplina de Matemática, mas quando chegámos a Fonte Boa fomos informados de que não havia professores de Português suficientes, pelo que ele teria de leccionar esta disciplina, mesmo não tendo qualquer formação específica neste domínio. 
se passará com os outros professores... Mas dado que o formalismo impera neste país, acredito que seja também um mero pro forma.

Um outro mecanismo de controlo são as aulas assistidas, quer pelo director pedagógico, quer pelos colegas do grupo de disciplina. Tanto eu como o Carlos já tivemos uma aula assistida, de surpresa, pelo director pedagógico. Ao desempenho dos professores é depois atribuída uma nota de acordo com uma grelha de bons e maus procedimentos pedagógicos (o curioso é que nessa tal grelha não há qualquer item que diga respeito à (in)correcção científica!).

Pois nunca eu imaginei que vinha para Moçambique fazer planificações completas de todas as aulas, ter aulas assistidas e ser avaliada pelos colegas e pelo director pedagógico! Mas vá lá, mesmo sem estágio, quatro anos de experiência a dar aulas já dão para aprender alguma coisa e a nota que o pedagógico me atribuiu na aula assistida, depois de preenchida a tal grelha e feitas as contas ao número de "sins", "nãos" e "às vezes", foi de 20 valores! Obviamente, uma farsa ou, quando muito, uma mera formalidade. Tenho consciência de que a aula me correu bastante bem (era correcção do teste), mas também sei que não cumpro à risca todos aqueles itens. Mas acho que, de certo modo, o director pedagógico se sente algo intimidado com as minhas habilitações científicas e pedagógicas... Quanto ao Carlos, também não se saiu nada mal para principiante e teve 18,4 valores na aula assistida. Esta semana começam as aulas assistidas pelos colegas: the show must go on...

Estas observações, registadas um mês após o início das aulas, não só deixam transparecer as minhas resistências internas em submeter-me às regras do sistema de ensino moçambicano, como fazem já adivinhar uma série de tensões entre nós e a escola que viriam a manifestar-se mais tarde, umas vezes abertamente, outras de forma mais velada. O relacionamento com a comunidade docente foi, sobretudo no primeiro ano, difícil, irregular e atravessado por uma série de questões que se prendem com expectativas e preconceitos quanto ao nosso papel e comportamento, mas também com a projecção da imagem do "leigo" criada por voluntários anteriores. O nosso trabalho na escola foi inevitavelmente condicionado por relações de poder alicerçadas nos binómios branco/negro, português/moçambicano, colonizador/colonizado.

Para a maioria dos professores locais, a nossa presença era sentida como uma intrusão e uma ameaça. Intrusão, na medida em que a nossa prática pedagógica era estranha e alternativa ao seu método generalizado de 
ensino, e também porque, como voluntários da ONG, éramos professores na escola "por inerência", não estando sujeitos às mesmas burocracias contratuais do estado moçambicano. Por outro lado, a nossa presença na escola era vista como uma ameaça real às práticas de corrupção, de fraude e de favorecimento de certos estudantes, sobretudo nos conselhos de notas, onde a violação do regulamento de avaliação era comum. Aliás, o episódio de maior tensão entre nós e a comunidade docente ocorreu precisamente nos conselhos de notas do final do primeiro ano, por nos termos oposto abertamente à validação, nas pautas, de vários casos de fraude e nepotismo 7 .

Por esta mesma razão, a nossa presença suscitava, entre os 600 estudantes da escola, duas posições contrárias. Uma parte sentia-a como desejada, quer pelos métodos pedagógicos que adoptávamos, centrados na aprendizagem activa dos jovens, quer pelo facto de a nossa simples presença na escola ser já um factor de inibição das práticas ilícitas (compra de notas, favores sexuais entre professores e alunas, favorecimento explícito dos estudantes que são familiares dos docentes) comuns no meio escolar. A outra parte dos estudantes, sobretudo os que estavam habituados a obter as classificações por meios ilícitos, mantinham relativamente a nós uma atitude de hostilidade, embora não o assumissem frontalmente.

Ao racionalizar a experiência vivida no contexto docente, e em especial a convivência com os professores locais (frequentemente marcada pela desconfiança mútua), parece-me que a dicotomia colonizador/colonizado continua a ser organizadora das relações a nível educativo. Ainda que o contexto histórico seja hoje muito diferente, as expectativas e preconceitos face ao nosso papel não deixavam de estar associadas ao estereótipo do branco, entendido como aquele que outrora estabeleceu uma relação de dominador/ dominado e agora, por "sentimento de culpa", a substitui por uma dependência de assistente/assistido, mas como forma velada de neocolonialismo.

${ }^{7}$ Apesar de os nossos esforços terem sido no sentido de nos integrarmos e submetermos às práticas e políticas do sistema de ensino onde fomos incorporados, houve três situações em que, por imperativos éticos pessoais, limitámos deliberadamente a nossa participação. Tomámos a decisão de não pactuar com fraudes nos conselhos de notas e de não respeitar a norma que proíbe os estudantes sem uniforme de assistirem às aulas e a norma que proíbe a utilização das línguas maternas no recinto escolar. Burgess (1997: 110) chama a atenção para a necessidade de o investigador tomar decisões acerca da extensão em que vai participar, pois de outro modo pode cair em situações de observação participante que violem a sua própria posição ética. 
A questão da "dívida histórica" dos portugueses para com os moçambicanos, por causa da escravatura e da colonização, foi muitas vezes publicamente levantada pelos professores locais para justificar, por um lado, os pedidos materiais e os favores que nos solicitavam; mas, por outro, para frisar que as posições se inverteram e os professores portugueses, agora, já não gozam de uma posição privilegiada dentro do sistema e apenas têm que submeter-se à nova ordem ditada pelas autoridades moçambicanas.

Assim, para a generalidade dos professores locais, éramos sempre uma presença incómoda: ou porque a nossa diferença cultural e académica era vista como uma ameaça, ou porque a condição de portugueses acordava o fantasma do neocolonizador. Este receio de uma nova forma de "colonização cultural" era agravado até pelo nosso papel como professores de Português, que, sendo a língua oficial de Moçambique, não é nem natural nem consensual ${ }^{8}$.

\section{"Professora, corar é o quê?" - ensinar e aprender Português como língua "outra"}

Num contexto em que os docentes moçambicanos se vêem obrigados a ensinar um padrão linguístico - o português europeu - de que nem eles próprios nem os estudantes têm experiência directa, a nossa intervenção na escola, na qualidade de professores portugueses, tinha como objectivo permitir o contacto directo de discentes e docentes com falantes nativos da norma europeia do português.

Antes da partida para o terreno, nunca antevira o ensino da língua portuguesa como um domínio onde viesse a encontrar grandes desafios de adaptação, pois partia do pressuposto ingénuo de que os estudantes compreendiam a língua oficial do país. O confronto com a realidade local viria a colocar-me perante a necessidade inesperada de ter de me adaptar à minha própria língua materna, para a ensinar como língua "outra", estranha e estrangeira.

As questões da comunicação e da linguagem, da aprendizagem das línguas (as minhas tentativas de aprender cinyanja e as dificuldades que senti em ensinar português) foram um dos aspectos mais marcantes da fase

\footnotetext{
${ }^{8}$ Vários professores e estudantes da região defendem abertamente que a língua oficial em Moçambique deveria ser o inglês.
} 
de adaptação ao terreno. Durante os primeiros meses, várias gaffes que cometi me levaram a perceber a ligação estreita entre linguagem, cultura e sociedade. Recordo aqui um episódio que me serviu de lição.

No primeiro teste de avaliação que dei nas minhas turmas, procurei com cuidado escolher um texto com vocabulário acessível, com uma linguagem simples, com poucas marcas culturais e cujo contexto se aproximasse das vivências na escola. Optei por um excerto de um romance juvenil, de autora portuguesa, que relatava uma situação em sala de aula. Mas passou-me completamente despercebido um pormenor: o texto dizia que a protagonista, ao receber um bilhete amoroso, desatara a "corar de vergonha".

Só então me dei conta, na prática, do quanto língua e cultura são indissociáveis do nosso quadro mental (e até da cor da pele), quando percebi que nenhum dos meus 150 alunos e alunas sabia o que significava "corar". E nem eu própria consegui, depois de várias tentativas, que eles compreendessem o sentido desta palavra. De facto, cada língua transporta uma determinada visão do mundo e é preciso um descentramento da identidade para conseguir aprender e ensinar noutro quadro linguístico e cultural.

De certo modo, a minha familiaridade com a língua portuguesa tinha de ser desconstruída. Com a repetição de alguns episódios como este, fui percebendo que teria de olhar e ouvir as palavras como se o fizesse pela primeira vez, com espanto inicial, num constante processo de passar da proximidade ao distanciamento, para ser capaz de, com os meus alunos e alunas, fazer esse caminho de aproximação às palavras desconhecidas.

16 de Fevereiro de 2003

De facto, é assustador o desconhecimento que têm da sua língua oficial. E mais assustador ainda é que os programas da disciplina sejam muito semelhantes aos de Portugal, sem ter em conta que o português não é a língua materna destes meninos e que a maior parte deles só a começa a aprender no $6^{\circ}$ ano. É um trabalho complicado ter que cumprir o programa à risca - $\mathrm{o}$ director da escola está sempre a pressionar-nos por causa das brigadas de fiscalização - com alunos que não sabem o vocabulário e a gramática mais elementar... Apesar de todas as limitações e frustrações, estou a gostar de dar aulas de Português ao $8^{\circ}$ ano e, embora muito raros, também tenho bons alunos (sobretudo os mais pequeninos, de 12 e 13 anos). 
Estas observações de terreno relativas ao fraco domínio do português são corroboradas por estudos recentes sobre a apropriação da língua portuguesa em Moçambique ${ }^{9}$. No meio rural, o português, não sendo uma língua indispensável à sobrevivência económica da população, é usado em contextos muito restritos. Além disso, é ensinada por professores que, na maioria dos casos, nunca tiveram contacto com a norma europeia nativa, sendo aprendida como segunda língua por crianças que, pelo menos nas comunidades rurais, apenas têm acesso ao português nas escassas horas que passam na escola, tornando-se o desconhecimento desta uma das principais causas do alto índice de insucesso escolar (Gonçalves, 2004: 232).

Tanto quanto pude perceber a partir das conversas com os meus alunos e alunas e através de algumas experiências de leitura que fiz com crianças da primária a partir dos seus manuais, o ensino do português nos primeiros anos de escolaridade não tem em conta que se trata de uma segunda língua, nunca usada fora do contexto escolar. Pelo contacto que tive com essas crianças e com os seus trabalhos de casa, concluí que os próprios professores saberiam muito pouco da língua que ensinavam. Aliás, esta insegurança linguística dos professores primários tem sido salientada por vários estudos referentes ao ensino do português em Moçambique ${ }^{10}$.

Aquilo que se verifica, sobretudo nas zonas rurais, é a aquisição do português como língua não materna, num contexto em que os aprendentes não têm acesso à norma nativa europeia, nem em ambiente natural, nem

${ }^{9}$ Sobre este assunto veja-se a bibliografia citada por Gonçalves (2004: 241-242).

${ }^{10}$ Cf. Gonçalves (2004: 236): "Actualmente, a norma oficial preconizada como alvo não é, de facto, usada pela maioria dos falantes do Português de Moçambique, incluindo os próprios professores encarregados de a transmitir. Cria-se assim uma notória «discrepância entre a política educacional para o ensino do português em Moçambique e o uso diário desta língua na escola moçambicana» (Nhampule e Martins, 1999). Como consequência, os professores primários, que deveriam ter um papel decisivo na transmissão desta norma, experimentam «uma grande ansiedade e insegurança linguística ao lidarem com a língua portuguesa», as quais podem ser atribuídas ao facto de a sua própria variedade do Português ser diferente daquela que se encontra nos livros escolares (Hyltenstam e Stroud, 1997: 84). Por outras palavras, no momento presente, os próprios agentes encarregados de reproduzir a norma oficial são obrigados a instruir em/e através de uma forma de Português na qual não se sentem confortáveis. Esta situação, como sublinha Stroud (1997: 26), «coloca um dilema para a educação em Moçambique, nomeadamente a necessidade prática de ensinar em/e através de uma norma linguística que dificilmente se encontra no uso geral, tanto fora como dentro dos estabelecimentos educacionais», acabando os professores por fornecer aos seus alunos «modelos de inconsistência» linguística." 
através de instrução formal, nem sequer através dos meios de comunicação social. E embora os planos curriculares do ensino primário prevejam o ensino formal do português desde a $1^{\mathrm{a}}$ classe, o que acontece na realidade dos meios rurais é que esta aprendizagem muitas vezes só se concretiza a partir do $6^{\circ}$ ano.

Num questionário de diagnóstico que passei aos cerca de 150 alunos e alunas das minhas três turmas do $8^{\circ}$ ano, a grande maioria disse ter começado a aprender português no $6^{\circ}$ ano. Apenas os poucos alunos oriundos da cidade de Tete referiram ter começado a aprendizagem da língua em casa ou na escola primária. Esta diferença entre a aquisição da língua em meio urbano e meio rural cria disparidades socioculturais e educativas bem vincadas. De um modo geral, os alunos com melhores notas a português e nas outras disciplinas eram os da cidade.

Além do desfasamento etário na aprendizagem da língua portuguesa entre estudantes da cidade e do campo, verifica-se uma discrepância entre a política educativa para o ensino da norma europeia do português, oficialmente estabelecida como padrão, e o uso quotidiano desta língua na escola moçambicana, em particular nos meios rurais. A estas disparidades acresce ainda o (incompreensível) facto de, em Moçambique, os programas curriculares da disciplina de Português serem muito semelhantes aos programas adoptados - para o mesmo ano de escolaridade - em Portugal, onde o português é língua materna ${ }^{11}$.

O ensino do português enferma, assim, de uma série de discrepâncias que se sobrepõem e que perpetuam, através do sistema educativo, as desigualdades sociais. Além disso, a escola desenvolve práticas de avaliação que acentuam as diferenças de capital linguístico, colocando precocemente fora do sistema de ensino alguns estratos da população escolar e tornando-se um instrumento de selecção com base nas capacidades pessoais e no background linguístico de que os discentes são portadores. $\mathrm{O}$ ensino formal do português contribui, pois, para um sistema educativo onde se processam fenómenos

${ }^{11}$ Cf. Dias (2005: 2): “O ensino e a aprendizagem desta língua enfrentam conflitos de carácter macrossociolinguístico e microcurriculares sendo de destacar dois mais agudos: (i) ao nível macrossociolinguístico, o conflito político-linguístico entre a norma-padrão europeia e as normas não-padronizadas moçambicanas e (ii) ao nível microcurricular, o conflito pedagógicodidáctico entre a Pedagogia e a Didáctica Tradicionais predominantes nas escolas e a diversidade e heterogeneidade da população estudantil." 
de reprodução social e cultural e o fracasso escolar se explica através do conceito de violência simbólica (Bordieu e Passeron, 1970).

A necessidade de ensinar português aos meus alunos e alunas como língua "outra" chocava com um sistema escolar caracterizado por uma organização curricular rígida e prescritiva, com dificuldade em lidar com as diferenças individuais e com a diversidade social e linguística que caracteriza a escola moçambicana. Porém, a nível político, compreende-se esta opção: sendo a aprendizagem da língua portuguesa um veículo para a unificação nacional e a construção identitária, o ensino do português ultrapassa o âmbito puramente linguístico e assume-se como uma questão de política educacional e patriótica. Assim, é necessário manter uma língua de instrução e uma norma-padrão comum a todos, independentemente do grande impacto das normas não padronizadas na fala dos estudantes e professores.

Como salienta Dias (2005: 4), em países multilingues e multiculturais, como é o caso de Moçambique, os governos definem políticas linguísticas e planificam currículos movidos pelo desejo de agregar as populações em torno de um certo ideal de construção da unidade nacional. Mas, apesar de a língua oficial e de instrução aparecer como um sistema simbólico que permite que a escola realize a sua função ordenadora - pois é entendida como elemento agregador e unificador - essa língua não deixa de conter em si algo de desagregador, na medida em que, ao mesmo tempo que une, exclui todos os que não a utilizam.

Depois da nossa experiência lectiva numa escola rural de Moçambique, concordamos inteiramente com a opinião de Dias (2005:1112): "O conflito pedagógico-didáctico existente é que a Pedagogia e a Didáctica do Português deveriam ter em consideração a diversidade, a heterogeneidade e as diferenças entre os alunos, e ter como fontes curriculares primordiais o aluno (sujeito de aprendizagem) e a sociedade moçambicana que é multilinguística, multicultural e socioeconomicamente estratificada. Em vez disso temos um currículo cuja fonte predominante da teoria e prática do desenvolvimento curricular são os conteúdos."

Muitas vezes me interroguei que sentido faz ensinar a estudantes moçambicanos do $8^{\circ}$ ano como se redige uma acta ou um relatório, se nem sequer conseguem entender o que soletram. Que sentido faz ensinar a função fática da linguagem, com exemplos de conversas telefónicas do manual, se a quase totalidade nunca viu ou usou um telefone? Mas qualquer desvio ao programa curricular estabelecido a nível nacional não era permitido pela 
direcção pedagógica da escola, que antes de cada aula tinha de dar o seu aval aos conteúdos a leccionar ${ }^{12}$.

Sem grande margem para poder alterar o programa curricular dentro da sala de aula, foi necessário procurar estratégias para ajudar os alunos e alunas na aquisição de competências na língua portuguesa através de contextos educativos informais, e tanto quanto possível lúdicos, pois, sendo o Português uma disciplina estigmatizada por um insucesso escolar considerável, havia muitos estudantes com alguma resistência à aprendizagem desta língua.

16 de Fevereiro de 2003

No fim-de-semana passado, fizemos um concurso a propósito do filme que passámos. A ideia é incentivá-los a ler as legendas, porque, segundo nos disse a Ana, a maioria não as lê. Fiz seis perguntas cuja resposta implicava a leitura das legendas. Eles ficaram entusiasmadíssimos com o concurso e vários foram munidos de papel e caneta para a sessão de cinema. Houve muitos concorrentes e vários alunos que acertaram. Fiquei muito satisfeita com os resultados. Esta semana vou fazer outro concurso, mas que implica relacionar uma parábola com a mensagem do filme. Percebi que as legendas até as podem ler, mas muitas vezes têm enormes dificuldades em interpretar o que lêem e em perceber a história.

\section{“Professora, o que é um arquétipo?" - o papel da educação informal}

A biblioteca e o alpendre de nossa casa foram espaços privilegiados de observação e em que a relação com os alunos e alunas se revelou muito proveitosa, em situações de educação informal, liberta dos constrangimentos impostos pelos formalismos da sala de aula. Nestes espaços, a aprendiza-

${ }^{12}$ Cf. Dias (2005: 13-14): “O nosso ensino caracteriza-se por ser verbalista, livresco e dogmático. O professor é a autoridade máxima e a aula gravita à sua volta, sendo sua tarefa principal expor oralmente a matéria. Os alunos permanecem quietos e calados. As aulas de Língua Portuguesa são marcadas pela monotonia e por rotinas repetitivas (ler textos, explicar o vocabulário desconhecido, interpretar os textos, fazer exercícios de gramática e escrever o sumário) que não apelam à participação efectiva do aluno e não o estimulam a desenvolver a comunicação. O ensino é livresco, pois os professores prendem-se aos livros e limitam-se a reproduzir o que os manuais recomendam, sem se preocuparem em atender aos ritmos diferenciados de aprendizagem. O ensino é dogmático no sentido que a matéria é apresentada na forma de verdades indiscutíveis e espera-se que o aluno decore os conhecimentos e que depois seja capaz de reproduzi-los nos momentos de avaliação." 
gem da língua portuguesa acontecia "naturalmente", sem necessidade de a espartilhar em categorias gramaticais ou em listagens de vocabulário. Foi na biblioteca que consegui apreender muito das expectativas, interesses e dificuldades dos estudantes e dos professores, quer através de conversas ocasionais, quer através dos registos das requisições.

16 de Fevereiro de 2003

Quanto aos nossos projectos, já estão todos a funcionar. A biblioteca é o que me dá mais satisfação. Na primeira semana de funcionamento tive de lá estar todas as tardes porque o funcionário é novo neste trabalho e precisava de orientação e ajuda. A biblioteca tem uma enorme afluência e dá gosto ver que é tão útil aos alunos. Requisitam sobretudo livros de estudo (convém lembrar que aqui os alunos não têm livro a nenhuma disciplina), mas muitas vezes precisam de orientação para escolher o livro adequado à matéria que pretendem estudar. E é aí que eu posso ajudar. Mas agora que o funcionário já se orienta sozinho, só dedico uma tarde por semana para lá estar. No outro dia gostei muito de estar a ajudar um grupo de alunos do $10^{\circ}$ ano a fazerem o TPC de Português, que consistia em descobrir recursos estilísticos num determinado texto. Conheciam muito poucos e não sabiam identificá-los, e então estive a explicar-lhes. Estiveram interessadíssimos e acho que aprenderam mais nesse bocadinho do que numa aula inteira.

O meu trabalho na biblioteca também passa por ajudar os professores, nomeadamente a encontrarem o livro certo para a matéria que pretendem e a saberem utilizar/ler um índice! Outra coisa que também me dá grande satisfação é perceber que há um aluno que todos os dias lê um livro novo, habitualmente de literatura juvenil ou policiais. A princípio desconfiei que lesse, de facto, um livro por dia, até que lhe perguntei se ele lia mesmo os livros ou apenas lia parte a ver se gostava... Ele respondeu: "Leio todos os livros até ao fim! E se a professora quiser posso lhe contar a história de todos os que já li este ano..." Eu acreditei (até porque foi ele o vencedor do concurso sobre um filme que passámos, tendo respondido acertadamente a todas as perguntas, e num português muito correcto). Entretanto, comentei com o funcionário da biblioteca que estou com vontade de dar um livro-prémio a este aluno no final do trimestre, e ele disse-me que há mais dois alunos que também quase diariamente requisitam um livro novo. Assim dá gosto... 
Ainda antes do início do ano lectivo pude perceber, através da consulta dos registos da biblioteca do ano anterior, qual a tipologia dos livros mais requisitados. Além dos manuais escolares, destacavam-se as revistas portuguesas de actualidades e, para meu espanto, os manuais de filosofia (disciplina que só é leccionada nas escolas de ensino pré-universitário).

12 de Janeiro de 2003

Uma outra maneira de ajudar pode ser adquirir, para a nossa biblioteca, revistas de actualidades (mesmo que ao chegarem já tenham perdido alguma actualidade). Este tipo de revistas tem muita saída entre os alunos (convém lembrar que por cá não há jornais nem televisão...). A nossa biblioteca está mais ou menos bem apetrechada (é a maior de toda a Angónia, com cerca de 2.500 livros), mas há alguns assuntos em que podia ser enriquecida. Por exemplo, os alunos parecem gostar bastante de livros de filosofia (não sei até que ponto os entendem, mas são bastante requisitados).

Com o tempo, a observação e o contacto com os estudantes (que se tornava muito mais próximo e desinibido no espaço da biblioteca), fui percebendo o que os atraía nas revistas de actualidades e nos livros de filosofia. As revistas eram procuradas não pelas notícias em si, que poucos liam, mas pelas fotografias de um mundo "outro", estranho, distante, cheio de objectos que nunca viram, habitado por "pessoas bonitas" ( $\mathrm{sic}$ ). As revistas eram um mundo de alteridade, de fascínio, de diversidade cultural, onde se plasmava diante dos olhos tudo aquilo que não conheciam e lhes era fascinantemente diferente. Este interesse pelas revistas era extensivo às crianças pequenas que frequentavam a Missão, mas não a escola e a biblioteca. Todos os dias havia meninos e meninas a instalarem-se no nosso alpendre e a bater à porta com o seu "Estou pidir rivista..."

O interesse dos alunos mais velhos - a frequentar o $9^{\circ}$ e $10^{\circ}$ ano, com idades entre os 15 e os 17 anos - pelos livros de filosofia intrigava-me muito nos primeiros tempos. Não era uma disciplina do seu currículo, exige uma abstracção mental que pressupõe um bom domínio - que não tinham - da língua em que os conceitos são verbalizados, implica o conhecimento de um paradigma cultural que lhes é alheio. Mas, apesar de tudo isto, os poucos manuais de filosofia que existiam na biblioteca eram diariamente requisitados e disputados. Mais tarde vim a perceber que leigos portugueses e escolásticos moçambicanos lhes tinham despertado o interesse pela filosofia como o 
domínio do saber que procura as respostas para interrogações como: quem somos?, o que é a liberdade?, como distinguir o bem e o mal?

16 de Fevereiro de 2003

Bom, mas no meio deste desconhecimento todo, há alguns alunos que nos surpreendem. Um deles é o Luciano, do $9^{\circ}$ ano, que gosta muito de filosofia (todas as tardes lá vai à biblioteca requisitar um manual de filosofia) e por autodidactismo andou a estudar (com apontamentos e tudo) os pré-socráticos. Agora anda em Platão. De vez em quando, vem pedir-me para lhe explicar alguns conceitos. Um dia, estava eu na papelaria, apareceu para eu lhe explicar o que era um arquétipo. A princípio vi-me "grega", mas acho que lá consegui que ele percebesse, porque uns dias depois, com muita propriedade e oportunidade, ele utilizou essa palavra numa conversa que nada tinha a ver com filosofia. O Luciano é um rapaz muito engraçado. No outro dia quis que eu the explicasse porque é que a liberdade não é um acto espontâneo. No fim-de-semana passado, apareceu-me com algumas perguntas de filosofia para eu responder, desejando-me boa sorte e dizendo que depois ia corrigir as respostas e dar-me uma nota...

Estas observações dão conta de vários aspectos muito interessantes em termos educativos. Por um lado, como é que alguns alunos constroem o seu currículo alternativo, dedicando o tempo de "estudo obrigatório" a estudar, por genuíno interesse, uma disciplina que não consta do currículo que lhes é imposto pela escola ${ }^{13}$. Por outro lado, este exemplo dá conta do papel fundamental que outros espaços informais desempenham para a aprendizagem. Aliás, a sala de aula era considerada não como um espaço de aprendizagem privilegiado, mas como o território em que se exerce a autoridade do professor. Assim, qualquer questão colocada ao docente era por este entendida como um acto de indisciplina. Por esta razão, as dúvidas dos alunos e alunas, silenciadas na sala de aula, acabavam por convergir para a biblioteca ou, depois de já termos ganho a sua confiança, para o alpendre de nossa casa.

${ }^{13}$ Um outro exemplo desta apropriação, por parte de alguns alunos, das rédeas da sua educação é o Humberto, leitor compulsivo e com um grande domínio da língua portuguesa (apesar do seu background rural e de pobreza), que, durante as aulas de Português e Inglês (língua que também dominava), se abstraía do monólogo do professor sobre as regras básicas da gramática para se dedicar, às escondidas, à leitura de livros que escolhia na biblioteca. 
Este episódio deixa ainda perceber que os alunos e alunas entendiam como diferente a relação pedagógica que estabelecíamos com eles. O Luciano, ao trazer-me perguntas de filosofia para eu responder e ele corrigir, toma uma iniciativa que pressupõe uma inversão de papéis, algo impensável com um professor local, pois seria logo entendido como acto de insubordinação ${ }^{14}$. No entanto, esta atitude do aluno é, de certo modo, uma forma de resistência à disciplina e sintomática da necessidade que sentem de práticas pedagógicas alternativas, de romper com a homogeneidade dos processos de ensino.

Situações como esta fazem-nos questionar o que é que os alunos e alunas fazem daquilo que queremos fazer deles e delas. Ao mesmo tempo revelam como os estudantes têm clara consciência da importância da educação para o seu desenvolvimento pessoal, social e até para a sua construção identitária. Isto vai para além do reconhecimento geral do papel que a escola desempenha na fuga à pobreza, pois é praticamente a única possibilidade de que estes jovens dispõem para tentar escapar ao destino imposto pelas estruturas sociais em que vivem.

\section{"Uma mulher educada vale mais do que dez homens educados" - a questão do género}

A história pessoal e a experiência do investigador tornam-se decisivas na produção de informação (Burgess, 1997: 96). Inevitavelmente, as minhas observações no terreno foram condicionadas por aquilo que me era mais próximo ou me perturbava com mais intensidade. É, pois, de esperar que a minha condição como mulher, num contexto escolar vincadamente masculino $^{15}$, a minha identidade de género e o meu pensamento social sobre o assunto viessem a influenciar não só o trabalho de campo, como a própria percepção da realidade.

${ }^{14}$ Esta situação ilustra como, enquanto observadora participante, eu própria fazia parte do meio que estava a ser observado, modificando e influenciando o contexto de investigação e sendo eu própria influenciada por ele.

${ }^{15}$ No ano lectivo de 2003, eu e a Irmã Assunção (de nacionalidade espanhola) éramos as duas únicas professoras da escola num universo de 17 docentes. No ano lectivo de 2004, éramos três professoras (duas portuguesas e uma moçambicana) num universo total de 21 docentes. Entre a população estudantil, apenas cerca de 10\% a 12\% eram alunas. 
Também o discurso é condicionado pelo nosso trajecto de vida, que nos vai moldando e condicionando o modo como olhamos os outros ${ }^{16}$. Assim, os meus registos denunciam, em determinadas questões, um olhar marcadamente feminino, e até um certo comprometimento com as lutas emancipatórias das mulheres relativamente ao poder masculino. De facto, o confronto e o conflito entre a realidade quotidiana das mulheres (que eu observava) e os discursos politicamente correctos das autoridades e das orientações administrativas foram um dos centros de atenção das minhas análises no terreno. As notas que se seguem dão conta dessa minha implicação emocional e da própria subjectividade do discurso.

7 de Abril de 2003

Dia da Mulher Moçambicana

Não resisto a glosar Maria Velho da Costa, para escrevinhar, em tom de elegia/elogio, o quotidiano trágico-heróico de tantas Marias moçambicanas. Elas são mais de seis milhões, o dia não nasceu ainda, elas atam a capulana à cintura, amarram o bebé às costas e acendem o lume. As mamãs preparam o matabicho quando há pão para comer. As mamãs chamam ainda escuro os homens e as crianças, e enrolam as esteiras. As mamãs preparam as sacolas da escola, que costuraram a partir dos sacos de farinha timbrados USAid. As mamãs pilam o milho e cozem o feijão. As mamãs equilibram uma grande lata à cabeça, ajeitam o bebé ao peito para dar a mamada durante o caminho e percorrem quilómetros e quilómetros em busca de água. As mamãs embrulham a roupa suja numa capulana gasta, equilibram a trouxa à cabeça, voltam a encaixar o bebé às costas, e descalças palmilham, a pé e à chuva, os caminhos de matope até ao rio. Dobram-se em ângulo recto, com as pernitas do bebé balouçando-lhes pelos quadris, esfregam calças e camisas e capulanas com a barra de sabão amarelo, que está cada vez mais caro. As mamãs varrem a entrada da palhota com vassourinhas de palha e correm com os mosquitos que trazem a malária. As mamãs vão para a machamba, de enxada equilibrada à cabeça. As mamãs sacham e às costas o bebé chora com fome, elas capinam e às costas o bebé adormeceu. As mamãs vão para o mercado, de cestas à cabeça, e sentadas em ângulo recto vendem batatas e bananas. As mamãs contam os meticais para poder comprar uma barra de sabão. As mamãs aventuram-se pelo mato à procura de lenha e no regresso ladeiam as picadas com enormes feixes de ramos e troncos à cabeça. As

${ }^{16}$ Duas semanas antes da partida para o terreno, em 2002, eu defendera a minha tese de mestrado sobre "O mito das Amazonas no mundo grego", pelo que estava emocionalmente implicada e intelectualmente sensível às questões de género. 
mamãs cumprimentam os homens e os azungo com um "Muli bwanji?" e uma espécie de genuflexão da cabeça e dos joelhos. As mamãs chegam à palhota $\mathrm{e}$ acendem o lume. Mexem a massa nas panelas de ferro com vigorosos círculos do braço musculado. As mamãs preparam o caril com os restos do repolho. As mamãs servem o almoço aos seus homens, enchem-lhes os pratos de shima, mas não comem junto com eles. Elas pousam a carga na borda da estrada para aguentar... e não desconseguir o resto do caminho.

E enquanto as mamãs vão levando esta vida, o governo aposta fortemente na promoção da mulher. Ou, para utilizar uma expressão bem mais em voga, na promoção do género (por cá, "género" - entenda-se - é o sexo feminino). Mas a promoção da mulher, na maior parte dos casos, é conseguida somente à custa de cotas para as mulheres e avaliada por estatísticas do género. Por exemplo, em todas as escolas, para cada prova de avaliação que é feita aos alunos, é preciso depois fazer a percentagem de positivas do género.

No outro dia, aqui na escola, houve uma reunião dos delegados de disciplina para avaliar a baixa percentagem de positivas do género, pois as escolas têm de atingir um limite mínimo de alunas positivas. (Contou-nos a Ana que no ano passado, nos conselhos de notas, várias alunas foram administrativamente aprovadas para cumprir a percentagem mínima do género.) É verdade que se nota uma grande preocupação e ênfase na questão da promoção da mulher, mas é pena que esta promoção apenas seja orientada e avaliada em termos de estatísticas. A situação real das mulheres não parece estar a ser muito promovida, pelo menos qualitativamente...

26 de Maio de 2003

Depois das danças e do hino nacional, cantado pelos alunos da Fonte Boa, o Governador deu início às cerimónias de legitimação de uma "autoridade tradicional". Para grande surpresa nossa, foi empossado como chefe da aldeia não um venerável régulo, mas uma anciã! Foi ela a escolhida pela população para rainha (versão feminina do régulo) e o Governador aproveitou para fazer um discurso sobre a promoção do género. Aqui ficam algumas notas: "Uma mulher educada vale mais do que três, cinco, dez homens educados"; "Elas são professoras, são médicas, são enfermeiras"17; "Na província de Tete já temos

${ }^{17}$ Note-se que o discurso do governador não deixa de denunciar a visão de que, para as mulheres escolarizadas, as profissões mais consentâneas com o trabalho feminino são aquelas que estão relacionadas com o "ensino" e o "cuidado". Isto está de tal forma interiorizado pelas raparigas que, ao questionar as minhas alunas sobre a profissão que gostariam de exercer, o leque de respostas que obtive foi limitado a "professora" e "enfermeira". Entre os rapazes, as opções eram muito mais variadas. 
duas mulheres como chefes de aldeia e no nosso governo $30 \%$ dos cargos são ocupados por mulheres"; "Meninas: estudem. Não queiram casar cedo. Primeiro estudar, depois casar." Curiosamente, a dita anciã empossada chefe é tão analfabeta que em vez de assinar os documentos teve de pôr a impressão digital.

Se é certo que, ao nível do discurso e de algumas práticas, se percebe o empenho político na "promoção da mulher", esta preocupação pode estar a ter consequências algo perversas ao nível das atitudes em contexto escolar, não se traduzindo numa efectiva diminuição das desigualdades estruturais entre homens e mulheres no domínio da educação. Como observa Roque (2005: 59), "o problema é que o facto de estar na moda ou ser politicamente correcto tende a esvaziar o conceito de Género, o que se traduz em abordagens pobres e contraditórias com os princípios da emancipação e da transformação social."

Parece-me que em Moçambique o conceito de género ainda não foi cabalmente assimilado e assumido por quem tem responsabilidades no âmbito educativo. Por outro lado, o termo está a ser mal entendido, sendo usado como sinónimo de mulher e não como um conceito que permite realçar a construção social e cultural da identidade masculina e feminina. Esta ideia de construção social é fundamental porque aquilo que é construído é susceptível de ser transformado. Este é um dos pressupostos fundamentais da perspectiva de género, ou seja, que se podem transformar as desigualdades que se construíram entre homens e mulheres.

No entanto, em Fonte Boa, as medidas decorrentes da adopção deste conceito não estão a ser entendidas como forma de equilibrar as relações de poder e promover a igualdade de oportunidades, mas como uma "cedência" paternalista e condescendente a fim de as raparigas figurarem nas estatísticas nacionais como tendo acesso a níveis mais elevados de escolarização e a cargos de "poder" ${ }^{18}$. O lugar que as raparigas ocupam nas estatísticas pode

${ }^{18} \mathrm{Um}$ dado que muito me surpreendeu no primeiro ano no terreno foi a constatação de que, no universo de nove turmas a funcionar na escola de Fonte Boa, o cargo de delegado de turma era ocupado por sete raparigas. Com o decorrer do ano lectivo, pude verificar que as únicas funções dos delegados de turma consistiam em trazer para e levar da sala de aula o giz e o apagador, transportar o livro de ponto, apagar o quadro no final de cada aula e denunciar actos de indisciplina dos colegas. Ou seja, ainda que o cargo de delegado de turma, teoricamente, se traduza na obtenção de algum poder, na prática está associado a tarefas como carregar objectos, limpeza e a funções de delator. Ainda que seja uma bom indicador para as estatísticas, a ocupação deste cargo por alunas pouco contribui para alterar as desigualdades ao nível dos papéis sociais. 
estar a ser uma cortina de fumo que esconde as expectativas pouco positivas, por parte dos rapazes e dos professores, sobre as capacidades pessoais e importância do acesso das raparigas a uma educação formal em termos iguais ao universo masculino. A construção social do que é ser rapariga na escola estigmatiza a generalidade das alunas como medíocres ou, na melhor das hipóteses, medianas, necessitando de benevolência para terem sucesso escolar. Em muitos casos, as próprias raparigas acabam por interiorizar este preconceito, de tal modo que não vêem na sua educação uma oportunidade de emancipação, apenas mais um domínio de inferiorização.

Uma distinção conceptual importante que a abordagem de género acarreta é a diferença entre posição e condição. A categoria condição alude a um dado concreto que descreve uma realidade - por exemplo, a não escolarização das meninas numa determinada localidade. Trata-se de uma condição a que estão expostas essas raparigas. A posição, porém, tem a ver com as hierarquias de género, as relações de poder, nas quais as mulheres ocupam habitualmente uma posição subordinada relativamente aos homens. Esta distinção entre posição e condição é muito relevante, porque permite pôr em evidência que muitas das medidas de promoção do género se orientam unicamente para modificar as condições das mulheres, mas não para alterar as relações de subordinação em relação aos homens. Ora, se não se modifica a posição, é muito provável que as mulheres continuem expostas a desigualdades.

\section{"Professora, vou desconseguir..." - educar (com) o Outro}

O primeiro ano no terreno correspondeu a uma longa fase de ajustamento ao novo contexto humano, social e cultural. Naturalmente, as observações e reflexões que registei nos primeiros meses denunciam esse processo de tentar encontrar o meu lugar nos lugares do Outro: outro país, outra organização identitária e pedagógica, outras lógicas, outros professores. No início do segundo ano, ao regressar a Fonte Boa depois de um mês de férias, senti-me a voltar a casa e a nossa chegada era também aguardada pela comunidade como se já pertencêssemos à terra. $\mathrm{O}$ segundo ano correspondeu, assim, a uma fase de integração na comunidade e, no contexto escolar, as relações fluíram com muito menos resistências recíprocas. 
final de Fevereiro de 2004

Eu e a Ana Maria asseguramos a disciplina de Português às quatro turmas da $9^{a}$ classe e este ano, como eu já conheço os alunos e eles o meu método de trabalho, as aulas têm corrido um pouco melhor e as frustrações são um pouco menos. No outro dia, numa das aulas, estive a dar alguns recursos de estilo, nomeadamente a onomatopeia, que eles ainda não conheciam. Foi uma animação o final da aula, com os alunos a darem exemplos de onomatopeias e a imaginarem como se escreveriam. O quadro ficou cheio de BRRRR, CHUACK, BONG, CLIC, SPLASH, TOCTOC, TRIM, POUCATERRAPOUCATERRA... E eu também me diverti muito a descobrir novas onomatopeias que eles usam por aqui.

Além das aulas, continuo responsável pela biblioteca. Também aqui houve uma mudança importante. A direcção da escola, e os próprios professores, quiseram que a biblioteca passasse a estar aberta durante todo o dia (no ano passado só abria da parte da tarde) e a escola disponibilizou-se para pagar um funcionário a tempo inteiro (até agora, o salário do bibliotecário dependia dos Leigos para o Desenvolvimento). Assim, desde o início de Fevereiro que a biblioteca está aberta de manhã e de tarde, e tem tido uma enorme afluência. Tanta, que o funcionário chega a não conseguir dar conta do recado sozinho e muitas vezes tenho de ir para lá ajudá-lo no atendimento aos alunos. Assim, tenho passado bastante tempo ocupada com a biblioteca, quer atendendo alunos, quer controlando e ajudando o novo funcionário, quer preparando algumas actividades de dinamização e incentivo à leitura e à escrita. De duas em duas semanas organizo um concurso de escrita criativa. É claro que os textos que eles escrevem são, no geral, muito fraquinhos, mas pelo menos são “obrigados" a usar a cabeça, que é coisa a que não estão habituados.

Ao longo do primeiro ano, graças às aulas assistidas nas turmas dos outros professores, constatei que as práticas de ensino local se baseiam numa lógica punitiva da avaliação e no receio de errar por parte dos discentes. Como observa Dias (2005: 17), isto desenvolve nos alunos e alunas atitudes de medo, de stresse, e por isso se mantêm tensos e calados durante as aulas, impedindo que o professor receba o feedback necessário para conhecer o grau de assimilação das matérias. Por outro lado, no domínio cognitivo, o nível de assimilação mais avaliado é a memorização. Estas práticas suscitaram algumas das passagens mais ácidas das minhas notas de terreno relativas à análise do sistema educativo moçambicano. 
final de Fevereiro de 2004

Nas aulas dos professores moçambicanos, os alunos são forçados a decorar definições e fórmulas matemáticas, e quase proibidos de pensar. Um aluno que questione o professor, que coloque dúvidas, que dê a sua opinião, é de imediato catalogado de indisciplinado e sujeito a ser expulso da escola, de tal modo que a maior parte dos alunos tem medo de abrir a boca. Quase todos os meus alunos incorrem numa tremenda e estupidificante preguiça mental e recusam-se a pensar. Tem sido uma luta conseguir levá-los a usar um pouco a cabeça, pois sempre que se faz uma pergunta que exige um mínimo de raciocínio, ou que não seja apenas reproduzir uma frase do texto ou do caderno, a resposta imediata é: "Professora, vou desconseguir...", ainda antes sequer de terem tentado pensar.

Abril de 2004

Os nossos alunos não aprendem: repetem, reescrevem, reproduzem palavras que desconhecem, números que não entendem, desenhos que inimaginam. Este ensino-desaprendizagem que grassa pelas escolas de Moçambique não está a formar "os homens de amanhã", mas a formatar as cabeças dos alunos, como se as suas mentes fossem objectos igualitários numa fabril e febril linha de montagem, cujo resultado final deve ser uma cópia fiel do seu modelo: o espírito quadrado e "quadri-colado" do professor! Entristece isto... A maior parte dos professores moçambicanos censura a dúvida, cala a opinião pessoal, impede a participação, corta as asas da criatividade, impõe a fórmula, exige a resposta uníssona, promove a repetição e a cópia.

Apesar de tudo, a escola da Missão de Fonte Boa é a mais bem cotada da província de Tete, em termos de exigência e nível intelectual. Não que estes professores sejam bons ou melhores do que os outros, mas porque, pelo menos, a maior parte dos alunos obtém as suas notas por mérito e não por "cabrito". Falo aqui do cabrito-metáfora, do cabrito "trago-lhe-aqui-um-presuntinho". Falo desse outro cabrito que é o "abra-da-cabra" para se conseguir alguma coisa neste país. Na escola secundária de Tete, não passa de ano um aluno que não paga cabrito ao professor (ou algum equivalente, que pode até ser uma aluna a cabriolar-lhe no capim...). Aqui a dois passos de nós, na Vila Ulongué, para se ter uma boa nota num teste, nem é preciso fazê-lo, basta pagar umas cervejas ao professor. E, assim, nas pautas de cada trimestre pululam os 18 e 19. Neste país, a inflação das notas é um problema bem mais grave do que a inflação económica! 
Em lugar da criatividade e da autonomia do trabalho docente, impera o formalismo, impedindo que o sonho, a imaginação, façam parte da prática quotidiana da escola. O que acontece é que os conteúdos das disciplinas são rigidamente definidos no âmbito macrocurricular, por planificadores do Ministério da Educação que depois enviam os programas, planos, materiais em forma de "pacotes curriculares" para serem consumidos pelos docentes (Dias, 2005: 16). Esta planificação centralizada não permite que professores e aprendentes exerçam a sua liberdade e autonomia criativa e contribui para a formatação das mentes dos alunos e alunas.

No entanto, tal intenção de homogeneizar e unificar encontra justificação em dois sentidos. Por um lado, a opção por uma planificação curricular centralizada tem em consideração o facto de a maior parte dos professores moçambicanos não ter formação adequada para leccionar nos níveis que the são atribuídos (Dias, 2005: 18). Por outro lado, em estados que se estão a consolidar, esta homogeneização é um objectivo deliberado para a própria constituição da identidade nacional ${ }^{19}$.

A questão da "domesticação das mentes", da penalização da criatividade e da diferença, e a preocupação nacional em homogeneizar os processos de ensino-aprendizagem conduz-nos a uma questão que atravessou o meu trabalho enquanto professora: o que fazemos, afinal, quando intervimos, quando educamos? Impor ou dar oportunidade de recriação? Ensinar a todos como se fossem um só ou potenciar as capacidades individuais de cada um?

Numa abordagem centrada no aluno, os professores são vistos como criadores de oportunidades pelas quais ensinam os aprendentes a "aprender a aprender". Alunos e alunas são encarados e valorizados como participantes activos que moldam as suas aprendizagens, tendo o professor como guia ou facilitador.

Enquanto professora defendo a maiêutica socrática como estratégia educativa e costumava colocar aos meus alunos e alunas questões cujas respostas não estavam plasmadas nos textos ou no manual. Muitas dessas perguntas interpelavam-nos directamente enquanto indivíduos. Como nota

${ }^{19}$ Cf. Cortesão (2001: 52-53): "Os professores seleccionados de camadas sociais relativamente homogéneas são «instruídos»e «preparados», de modo, até certo ponto, uniforme, através de currículos explícitos e ocultos (Bernstein, 1977) bastante semelhantes, vindo a constituir um corpo profissional relativamente coeso, cuja actuação contribui, corporativamente, para uma relativa uniformização do processo e que contribui ainda para que o poder e a influência do «Centro» se façam sentir mais intensamente na «periferia» do sistema." 
Caria (2002: 1415) "o etnógrafo nas Ciências Sociais não se limita a observar, a agir e a ouvir, faz, além disso, perguntas adequadas e pertinentes ao contexto, ainda que estas não sejam as que os autóctones verbalizam no quotidiano sobre o seu "nós". O investigador faz os nativos pensarem e verbalizarem sentidos e deterem-se sobre aspectos das suas vivências com os outros que, inevitavelmente, interrogam a sua identidade social e permitem estimular a sua reflexividade enquanto cidadãos."

Assim, sobretudo no decorrer do segundo ano, a minha principal preocupação foi apostar em práticas pedagógicas assentes no estímulo de atitudes críticas e indagadoras e na exploração da criatividade dos discentes. É neste contexto que os concursos de escrita criativa, dinamizados pela biblioteca à margem dos currículos da sala de aula, vieram a revelar-se oportunidades de aprendizagem e de produção cultural dos alunos.

final de Fevereiro de 2004

De vez em quando lá se encontram umas pérolas literárias quando eles se entusiasmam com a escrita. Vou transcrever aqui dois excertos de cartas de amor escritas por alunos, mas provenientes de duas situações diferentes. O primeiro é retirado de uma carta de amor que o Carlos encontrou, no final do ano lectivo, num dos computadores do centro de informática (nas horas de treino, o que os alunos mais gostavam de fazer era escrever às suas apaixonadas, em páginas emolduradas com corações!). A carta fora escrita por um dos alunos do curso, dirigida à sua "amada inesquecível", e por lá ficou esquecida num qualquer ficheiro. A carta de amor é toda ela um autêntico rebuçado literário, mas o mais delicioso é esta comparação: "Minha vida sem ti é como uma enxada sem cabo."

A ouvidos urbanos, esta frase desata, certamente, uma gargalhada. Pode até soar a uma paródia de carta de amor. Mas aqui, onde a vida das pessoas depende completamente da enxada, esta declaração é das mais genuínas, sentidas e bonitas que eu alguma vez encontrei. Poucos poetas terão dito tão bem...

A outra pérola provém de um aluno da $8^{\mathrm{a}}$ classe, participante de um concurso de escrita criativa, que consistia em escrever uma carta de amor sem utilizar a letra $\boldsymbol{e}$. No texto que escreveu, lê-se esta criativa comparação: "As tuas nádegas são como as almofadas do machimbombo quando salta nas curvas." É de uma sensualidade tão eloquente que lhe perdoei a letra $\boldsymbol{e}$ das nádegas e lhe atribui o $2^{\circ}$ prémio. 
Estas reflexões dão conta de uma viragem na minha própria forma de encarar a educação e o meu papel enquanto interventora na realidade educativa. Se, ao longo do primeiro ano, a minha atitude foi, sobretudo, a de educar o Outro, proporcionando aos alunos e alunas poucas oportunidades para a recriação dentro do seu quadro cultural, e impondo, talvez, modelos de pensamento ocidentais, no segundo ano, já com maior consciência do meu etnocentrismo inconsciente, da alteridade e diversidade sociocultural dos meus alunos e alunas e da questão da multiculturalidade, procurei adoptar uma perspectiva de educar(me) com o Outro. A forma como então interpretei "Minha vida sem ti é como uma enxada sem cabo" é sinal dessa mudança de atitude, reflectindo muito mais a minha transformação pessoal do que a dos meus alunos e alunas ${ }^{20}$.

Estas formas de os estudantes se exprimirem, que traduzem a sua mundivisão e o modo como vivem a sua juventude (e como encaram o amor), demonstram que pegaram na tarefa, a interpretaram e apropriaram. Ao contrário do que são formatados para fazer na sala de aula, estes alunos não reproduziram, não copiaram as palavras de amor de outros autores, não escreveram condicionados pelas minhas expectativas relativamente às suas produções.

Estes dois exemplos de utilização de linguagem metafórica, mobilizando objectos concretos do quotidiano, mas conferindo-lhes outros sentidos aparentemente estranhos e insólitos, são sintomáticos dessa capacidade e necessidade de recriação - até poética - por parte dos alunos ${ }^{21}$. Paul Willis defende que, em termos educativos, nós não reproduzimos apenas, mas produzimos cultura e resistimos à formatação. Estas produções em contextos informais permitem uma apropriação de imagens, objectos e significados culturais, levando os alunos e alunas a imaginar e produzir novos sentidos. Além disso, situações como estas - concursos de escrita criativa, treino livre individual nas sessões de informática - não só criavam oportunidades de

${ }^{20}$ Cf. Silva (2004: 569): "The writing of field-notes changes in its content and form, according to the growing familiarity we are achieving with things. Those notes allow us to understand the guidance lines of the investigation, the intentions, and our own selves that defile along with the records."

${ }^{21}$ Cf. Willis (2000: 36): "Cultural practices make creative use of provided services, objects and materials (meant to be private and consumed in line with dominant norms, institutional or commercial) to release their social potentials and produce aberrant decodings, uses and potentials never meant to be there." 
auto-aprendizagem para os estudantes, como se revelaram espaços fundamentais para a nossa própria educação intercultural com o Outro.

\section{"Professora, o teste era maningue big!" - eu sou aquilo que falo}

O meu papel como professora de Português permitiu-me um contacto privilegiado com as (re)produções e criações linguísticas dos falantes da Angónia. Também neste domínio as minhas perplexidades e percepções foram evoluindo ao longo do tempo. Se, nos primeiros meses, a minha surpresa e aprendizagem foi no sentido de me reconfigurar para ensinar o português como língua estranha ao Outro, posteriormente fui-me apercebendo com maior acuidade que os dilemas linguísticos dos estudantes não residiam apenas no conflito entre a língua materna e a língua de ensino - intensificado pelo problema de diglossia ao nível do português ${ }^{22}-$, mas eram ainda mais amplos, reflectindo a(s) sua(s) identidade(s) de fronteira.

Abril de 2004

Na cabeça de um homem há muitas línguas a falar diferente ${ }^{23}$. E, na cabeça dos nossos alunos, as muitas línguas a falar diferente ainda se complicam e "confusionam" mais com os dialectos a pensar diferente. Desconhecem fronteiras linguísticas, contrabandeiam palavras alheias. Falam com bocados umas das outras, e "texturam" textos que, espontânea e naturalmente, entretecem o português, o cinyanja e o inglês, compondo um mosaico multilingue. Exemplifico: "Professora, o teste era maningue big!"; "Estou pidir sweet. Não

${ }^{22}$ Gonçalves (2004: 237): “À semelhança do que acontece com os falantes de variedades não-nativas de uma forma geral, os falantes do Português de Moçambique distinguem-se por operarem com mais do que uma gramática, numa espécie de 'diglossia interna' (Lightfoot, 1991), que se exibe na co-ocorrência, no discurso de um mesmo falante, de formas convergentes com a norma gramatical do Português europeu e de formas desviantes a esta norma." Cf. ainda Dias (2005: 7): “Apesar dos preconceitos e da estigmatização existente em relação à variedade moçambicana da Língua Portuguesa, temos de reconhecer que esta variedade satisfaz plenamente as necessidades comunicativas dos seus falantes e reflecte a identidade sócio-cultural da comunidade de falantes da Língua Portuguesa em Moçambique. A variedade de Língua Portuguesa em Moçambique integrou de forma harmoniosa as culturas bantu e portuguesa e tudo leva a crer que ela é a principal depositária dos valores culturais "híbridos" dos moçambicanos."

${ }^{23}$ Em itálico, versos do poema As Linguagens de Mutimati Barnabé João (António Quadros). 
tem? Peço matsi"; "A Mphatso foi de ginga nas bancas comprar juice", "Yué, vai lá no internato levar jacket que o tempo não está nice" ${ }^{24}$. Frases poliglotas como estas são o padrão nosso de cada dia. A Ana Maria, que também dá aulas de Inglês, foi presenteada nos testes com algumas composições bem ilustrativas do discurso babélico. O tema das composições era a rotina diária dos alunos. Pois então: “I get up at 6.00 o' clock. I go no matabicho and I eat papas. At lunch I eat shima com caril." ${ }^{25} \mathrm{E}$ houve até alguns alunos que, depois de terem feito o resto do teste em inglês, chegaram à composição e a escreveram toda em cinyanja!

Como estamos a dois passos da fronteira (política) com o Malawi, a mestiçagem linguística que por aqui se fala está cheia de anglicanismos. É o caso de big, de uso generalizado mesmo entre os melhores falantes de língua portuguesa. Alguns alunos não sabiam sequer que big não é um termo português e muitos continuam a deixá-lo escapar mesmo nas minhas aulas. Mais comum ainda do que big, é a palavra nice para significar bem, bom ou bonito. Mas a minha predilecta, muito popular entre os alunos, é um híbrido inaudito: "shofista". E quem ficou a admirar maningue eu desconseguir o significado desta palavra foram os meus alunos, que logo prontificaram um exemplo vivente: "Aquele aluno da cidade, o David, é um shofista, cheio de estilo, sempre a exibir, a gingar..." Afinal?!!! Só então percebi que um "shofista" é alguém que está sempre no show off. 'Tá nice!

Este exemplo do "shofista", um entre muitos, é indicador das dinâmicas de apropriação de línguas estrangeiras em Moçambique e da readaptação que as comunidades operam em palavras que têm as suas origens noutros locais. A apropriação ocorre quando as práticas culturais combinam ou recombinam elementos seleccionados para produzir algo de novo (Willis, 2000: 75). Assim, inventar línguas que não estão reconhecidas é também uma forma de produção. Mas, dependendo da perspectiva de observação, estas inovações podem ser classificadas quer como "erros", quer como manifestações de criatividade.

${ }^{24}$ Segundo a norma-padrão do português: "Professora, o teste era muito grande"; "Estou a pedir um rebuçado. Não tem? Peço água."; "A Mphatso [nome feminino] foi de bicicleta às bancas comprar sumo"; "Ó pá, vai lá ao internato buscar um casaco que o tempo não está bom".

${ }^{25}$ Em inglês: "I get up at 6.00 o' clock. I go for breakfast and I eat porridge. At lunch I eat maize porridge with sauce." 
Esta "crioulização" da língua ${ }^{26}$, muito frequente entre os alunos e alunas de Fonte Boa, constitui um claro desvio à variante reconhecida como norma-padrão e as invenções lexicais apresentam-se aos professores mais como erros do que como neologismos. Coloca-se aqui a questão da legitimidade para a inovação linguística. Parte-se do pressuposto de que só aqueles que estão investidos de uma autoridade específica, como é o caso dos escritores, têm legitimidade e liberdade estética para romper com as normas linguísticas e recriar a língua. Mia Couto tem autorização (por isso é autor) para escrever como quiser, com as suas "brincriações" e ausência de fronteiras linguísticas, mas não se autoriza aos restantes falantes esta liberdade criativa, estigmatizando as suas "insubmissões" linguísticas como erros e insuficiente domínio da língua.

No seguimento das observações anteriormente transcritas a propósito do uso mesclado das línguas por parte dos meus alunos e alunas, tais exemplos suscitaram-me algumas reflexões sobre a íntima conexão entre língua e território cultural, língua e identidade, por um lado, e sobre a relação muitas vezes artificial entre pátria e fronteiras nacionais.

Esta quase esquizofrenia linguística parece-me ser o reflexo de uma sociedade de periferias, que culturalmente vive numa espécie de limbo. Os moçambicanos da Angónia pertencem maioritariamente ao grupo dos Angónis, o mesmo que vive do outro lado da fronteira, no centro e sul do Malawi, em torno do Lago Niassa. Em ambos os lados da fronteira política, e numa extensa área que se estende para o interior, moçambicanos e malawianos partilham a mesma cultura (nguni) e a mesma língua.

Não admira que as gentes da Angónia se sintam cultural e linguisticamente muito mais identificadas com o país vizinho. Além disso, durante os anos da guerra, muitas destas populações estiveram nos campos de refugiados do Malawi, sentindo-se lá como em casa. Muitos dos nossos alunos nasceram e cresceram nesses campos e alguns têm os irmãos a estudar do outro lado da fronteira. E muitos ex-refugiados por lá ficaram ainda. Compreende-se, pois, que os moçambicanos da Angónia se entendam melhor com os collegues

${ }^{26}$ Cf. "Creolization", in Encyclopedia of Social and Cultural Anthropology: "In recent anthropology the term has been widely used to refer to the creation of inter-cultural hybrids as a result of processes of globalization." 
"colingues" do Malawi do que com os seus conterrâneos da cidade de Tete, que falam uma língua alheia: o cinyungue ou o português!

E não é só na língua que estes moçambicanos e aqueles malawianos partilham a mesma pátria. Por cá, apenas se ouvem rádios da outra banda, se escuta e dança músicas malawianas. Até a moeda mais utilizada é a kwacha, em vez do metical! A própria Missão chega a pagar aos seus trabalhadores na moeda do país vizinho. Também os alunos muitas vezes nos vêm bater à porta para lhes trocarmos as kwachas por meticais, pois o internato (sempre é uma instituição do estado) tem mesmo de ser pago na moeda patriótica. Mas nas trocas mais ou menos informais, a situação é outra. Na moagem aqui da Missão, as mamãs pagam sobretudo com kwachas e no mercado da Fonte Boa as capulanas são mais baratas se pagarmos com dinheiro malawiano. Aliás, a maior parte dos feirantes vem do outro lado da fronteira e, ou nos entendemos por gestos (nem sempre universais), ou num inglês arranhado de meia dúzia de palavras. Assim, quando perguntamos o preço de um montinho de bananas ou de mangas, em vez de ouvirmos o típico e nacional "quinhento, quinhento" ou "mili, mili", é frequente ouvirmos como resposta "faivi [five] each". No mercado da vila (a $15 \mathrm{~km}$ ), a moeda usada já é quase só o metical, mas a língua de troca ainda é muitas vezes um malaviado inglês malawiano.

Esta permeabilidade local à influência malawiana não se fica por aqui. A maior parte dos nossos alunos compra e utiliza cadernos cuja capa adverte "Property of the Malawi Government - Not to be sold", em vez dos nacionais e mais patrióticos cadernos onde se lê "O progresso de Moçambique passa sempre por nós". Mas o que mais me surpreendeu foi encontrar, na palhota de um moçambicano, pendurado no lugar mais nobre da exígua sala, não o retrato do Chissano (que tem lugar cativo e altivo em todos os edifícios públicos), mas a fotografia emoldurada do Bakili Muluzi, o Presidente da República do Malawi! Quando admirei tão insólita ocorrência, na casa do filho do chefe da aldeia, fui assim explicada: "Desconsegui fotografia do Chissano, então pendurei essa própria do Muluzi. Precisava retrato de Presidente a guarnecer a sala..." E isto foi dito com tanta naturalidade que nem sei se é falta de patriotismo! Quase me apetece citar: Isto que faz na cabeça de um homem tirar retrato são línguas ${ }^{27}$. Pois se a minha pátria é a minha língua, logo o meu Presidente é aquele que fala a minha língua!

${ }^{27}$ Verso do poema As Linguagens de Mutimati Barnabé João (António Quadros). 
O certo mesmo é que as gentes de cá e de lá da fronteira parecem não se sentir muito identificadas (ou diferenciadas) nos seus oficializados símbolos nacionais. É verdade que nas capulanas usadas pelas mulheres moçambicanas podemos encontrar estampados o heróico busto e as palavras de ordem do Samora, o retrato patriótico do Chissano, a vitória olímpica da Maria Mutola a fazer publicidade aos telemóveis Mcel. Mas estas mesmas capulanas, de Samoras e Mutolas, também se usam do lado malawiano. Em contrapartida, não é nada improvável encontrar, do lado de cá, uma moçambicana com t-shirt da Frelimo e capulana do Muluzi! Não sei, pois, se todas estas manifestações são o resultado de uma crise de identidade, de uma falta de patriotismo ou de um excesso de pátrias: pátria cultural, pátria oficial.

Este longo excerto dá conta das minhas reflexões sobre a diversidade cultural com os seus múltiplos comportamentos e sobre a existência de várias identidades, vários territórios, sem fronteiras políticas, na vivência quotidiana e na mente dos habitantes da região. A identidade colectiva, construída com base na língua e cultura maternas, adquire aqui enorme importância na definição dos territórios de pertença, sobrepondo-se aos limites administrativos e nacionais preestabelecidos.

Não admira, pois, que nesta região a construção da identidade nacional dos moçambicanos continue a fazer-se por oposição aos portugueses, como antigos colonizadores, mais do que por contraponto aos vizinhos/familiares malawianos ${ }^{28}$. Por outro lado, esta vinculação étnica e linguística que aproxima as gentes da Angónia mais ao povo do país vizinho do que às gentes de Tete, a capital da sua província, torna ainda mais premente, no contexto das políticas de identidade, uma acção estatal orientada para a produção de símbolos, discursos e práticas que consolidem a consciência de pertença a um colectivo nacional - a nação moçambicana -, apesar da diversidade multicultural e linguística que a compõe.

${ }^{28}$ Cf. Ribeiro (2005: 258): “A construção da nação dependia, em boa medida, da eficácia da dicotomia nós, os moçambicanos, em oposição a eles, os colonialistas, fundada na experiência da opressão colonial que unia todos os povos que viviam sob o domínio português em Moçambique. Conquistada a independência, a construção da nação prosseguiu através da consolidação das estruturas jurídico-administrativas e da produção de discursos identitários orientados para o enraizamento da ideia de pertença a um colectivo nacional capaz de integrar e subordinar as diferenças fundadas na etnia, na língua e na religião.” 
É neste contexto que deve ser entendida a importância da escola e do ensino da língua portuguesa na construção do estado moçambicano, enquanto estrutura de socialização onde se garante a transmissão de uma cultura e língua nacional. Este papel decisivo que a escola assume na formação da consciência patriótica é bem evidente na rotina diária dos estudantes.

Abril de 2004

A falta de patriotismo (oficial) dos nossos alunos é umas das principais preocupações do director da escola. Todos os dias, antes das aulas da manhã e da tarde, alunos e professores têm de estar presentes na "concentração" para içar a bandeira e entoar o hino nacional. Cada turma tem a responsabilidade de cantar num determinado dia da semana. A seriedade do momento e a pose grave do director contrastam com a descontracção dos alunos, que ora cantam baixíssimo e sem convicção nenhuma, ora começam mal de propósito para terem que repetir mais uma vez, ora desafinam ostensivamente e terminam o hino numa risota geral. $\mathrm{O}$ director não se cansa de lhes fazer arengas patrióticas, mas nada... Infelizmente, o director anda mais preocupado com o fraco sentido patriótico dos seus alunos nesta terra de heróis, do que com o fraco sentido pedagógico dos seus professores neste país de muitos analfabetos.

\section{Ponto de partida}

As you set out for Ithaka hope the voyage is a long one, full of adventure, full of discovery.

Assim abri, com o poema Ithaka de Cavafis, as minhas notas de terreno em Janeiro de 2003. Previa que a viagem (etnográfica) seria cheia de descobertas sobre o Outro, mas não intuía ainda o quanto esta experiência seria cheia de descobertas sobre mim própria. Um olhar agora distanciado leva-me a concluir que esta transformação pessoal se adivinha já nas notas de terreno, pois a própria escrita muda com o decorrer do tempo e a progressiva integração na comunidade. O modo como fui escrevendo dá conta da evolução desse meu apego.

Chegado o momento da partida, dois anos volvidos, sentia-me em Fonte Boa como em casa, partindo já com o desejo de ali regressar. Revejo-me 
nessa identificação emocional do investigador com os indivíduos que observa, de que falam os etnógrafos à partida do terreno ${ }^{29}$. Tal proximidade afectiva não excluía, porém, a consciência das diferenças que nos separam. Há uma componente de estranheza, de enigma que vai sempre existir. Como escreve Burgess (1997: 99), "em situações em que brancos fazem investigação sobre negros, as pessoas podem tornar-se amigas, mas amigas que sempre permanecem de alguma forma estranhas umas às outras." O contacto diário com o Outro, a nossa imersão no terreno, provoca, muitas vezes de forma recíproca, uma abertura ao inesperado, uma ruptura com os estereótipos que trazemos, mas isto não pressupõe que somos todos iguais e gostamos muito das diferenças dos outros.

Hoje, à distância de mais de três anos sobre a partida do terreno, recordo sobretudo o plano afectivo do meu trabalho. Conceitos como alteridade, diferença, Outro, diversidade, língua, cultura, preconceito, género, educação, interculturalidade, ganharam rostos. Há algo de inside knowledge no que esta experiência me provocou. Por isso, sair de Fonte Boa, deixar os meus alunos e alunas foi, para mim - e espero que para eles e elas também -, um ponto de partida para um outro olhar sobre o mundo, sobre nós próprios. A um dos alunos, na despedida, não resisti a deixar-lhe a Ithaka de Cafavis, certa de que um dia também ele haverá de compreender estes versos finais:

Wise as you will have become, so full of experience, You will have understood by then what these Ithakas mean.

\section{Referências bibliográficas}

Bourdieu, P.; Passeron, J.-C. 1970. La Reproduction. Éléments pour une théorie du système d'enseignement. Paris, Édtions de Minuit.

Burgess, R. 1997. A Pesquisa de Terreno. Oeiras, Celta Editora.

Caria, T. (org.) 2002. Experiência etnográfica em Ciências Sociais. Porto, Edições Afrontamento.

${ }^{29}$ Cf. Fernandes (2002: 40): “O contacto próximo, quase físico, proporcionado pela postura etnográfica, não faz do investigador um autóctone. Mas é pleno de consequências muito para lá da esfera cognitiva que se crê levianamente ser a única que governa o pensamento científico. O desejo de regressar faz falar uma outra esfera que, dum modo mais subterrâneo, também o governa: a afectiva." 
Cortesão, L. 2001. Acerca da Ambiguidade das Práticas Multiculturais. Necessidade de Vigilância Crítica Hoje e Amanhã. In: Rodrigues, D. (org.) Educação e Diferença. Valores e Práticas para uma Educação Inclusiva. Porto, Porto Editora: 51-58.

Dias, H. 2005. Os conflitos no ensino/aprendizagem da Língua Portuguesa em Moçambique: caminhando para uma Didáctica da Heterogeneidade [Consultado em 25/05/2008]. http://web.educom.pt/ pr2002/pdf/ensino_aprendizagem_da_lp_em_mz.pdf

Fernandes, L. 2002. Um diário de campo nos territórios psicotrópicos: as facetas da escrita etnográfica. In: Caria, T. (org.). Experiência etnográfica em Ciências Sociais. Porto, Edições Afrontamento: 23-40.

Gonçalves, P. 2004. A formação de variedades africanas do português: argumentos para uma abordagem multidimensional. In: AAVV. 2005. A Língua Portuguesa: Presente e Futuro. Lisboa, Fundação Calouste Gulbenkian: 223-242. Portela, J. 2007. Escritas de Fonte Boa. Porto, Profedições.

Portela, J. 1985. Observação participante (reflexões sobre uma experiência). Cadernos de Ciências Sociais, 3: 157-176.

Ribeiro, F. 2005. A invenção dos heróis: nação, história e discursos de identidade em Moçambique. Etnográfica, 9(2): 257-275.

Roque, S. 2005. Género e Educação para o Desenvolvimento: quando o invisível e o não dito são o ponto de partida. In: AAVV. $a b c E D$ - Introdução à Educação para o Desenvolvimento. Instituto Marquês de Valle Flôr - Oikos: 56-64.

Silva, S. 2004. Doubts and intrigues on ethnographic research. European Educational Research Journal, 3(3): 566-581.

Willis, P. 2006. The Ethnographic Imagination. Cambridge, Polity Press.

Artigo recebido a 5 de Novembro de 2010 e aceite a 15 de Fevereiro de 2011. 